\title{
The Development of Children Pronunciation
}

\section{Perkembangan Cara Pengucapan Anak}

\author{
Sri Minda Murni* \& Mutsyuhito Solin
}

\author{
Fakultas Bahasa dan Seni, Universitas Negeri Medan, Indonesia \\ *Corresponding author: E-mail: srimindamurni@gmail.com
}

\begin{abstract}
The study is aimed at describing the pattern of a baby boy's pronunciation named Ghazi, 2.7 years old. The study focuses on the pattern of Ghazi's pronounciation of consonants in the initial and final position and vowels. The results show that: a) Ghazi finds difficulties in pronouncing some consonants in the initial position. The [p] and [b] phonemes become [t6] and [d] as in the example [psli] becomes [t6syi], [bsla] becomes [dsya]; Some phonemes are not spoken at all such as ' $m$ ' in [mobil] which becomes [Jbin]; b) Ghazi also finds it difficult to pronounce some consonants in the final position. For example, [apel] becomes [apan], [panjay] becomes [dadan], and [mundur] becomes [undun]; c) Ghazi finds some difficulties in pronouncing certain consonants in the initial position but not in the final position. For example, ' $t$ ' in the initial position is changed such as [toman] becomes [tcoman] but ' $t$ ' in the final position such as [pasawat]' becomes [tcutcawat] which shows no error; d) Ghazi's difficulties in pronouncing vowels are seen in the example such as [saram], [galap], and [karas] which become [tosyam], [djyap], and [toyas] in which that [o] phoneme becomes [0]. Other vowels do not result in similar difficulties for him. Further researchers are encouraged to find the uniqueness of every child's pattern of pronunciation to get insight on how children find their own way to a more accepted pronunciation.
\end{abstract}

Keywords: Development, Pronunciation, Children

\begin{abstract}
Abstrak
Penelitian ini bertujuan untuk menggambarkan pola pelafalan bayi laki-laki bernama Ghazi yang berumur 2,7 tahun. Studi ini berfokus pada pola pengucapan konsonan Ghazi di posisi awal dan akhir dan vokal. Hasilnya menunjukkan bahwa: a) Ghazi mengalami kesulitan dalam mengucapkan beberapa konsonan dalam posisi awal. Fonem [p] dan [b] menjadi [tc] dan [d] seperti pada contoh [poli] menjadi [t6əyi], [bola] menjadi [doya]; Beberapa fonem tidak diucapkan sama sekali seperti ' $m$ ' dalam [mobil] yang menjadi [obin]; b) Ghazi juga merasa sulit untuk mengucapkan beberapa konsonan di posisi akhir. Misalnya, [apel] menjadi [apan], [panjan] menjadi [dadan], dan [mundur] menjadi [undun]; c) Ghazi menemukan beberapa kesulitan dalam mengucapkan konsonan tertentu pada posisi awal tetapi tidak pada posisi akhir. Misalnya, ' $\mathrm{t}$ ' pada posisi awal diubah seperti [təman] menjadi [t6oman] tetapi ' $\mathrm{t}$ ' di posisi akhir seperti [pəsawat] 'menjadi [tcutcawat] yang tidak menunjukkan kesalahan; d) Kesulitan Ghazi dalam mengucapkan vokal terlihat pada contoh seperti [səram], [gəlap], dan [kəras] yang menjadi [t6əyam], [dəyap], dan [təyas] di mana fonem [ə] menjadi [э] ]. Vokal-vokal lain tidak menimbulkan kesulitan yang sama baginya. Peneliti lebih lanjut didorong untuk menemukan keunikan dari setiap pola pelafalan setiap anak untuk mendapatkan wawasan tentang bagaimana anak-anak menemukan cara mereka sendiri untuk pelafalan yang lebih diterima.
\end{abstract}

Kata Kunci: Perkembangan, Cara Pengucapan, Anak

How to Cite: Murni, S.M. \& Solin, M. (2018), The Development of Children Pronunciation. Analitika, 10 (1): $1-6$ 


\section{INTRODUCTION}

Children speech differs from that of adults in several ways. Language experts suggest that the difference is due to articulatory differences and vocabulary and syntax choices, in addition to the believe that children's production system which include vocal cords and vocal tract is shorter than adults' (Eskenazi and Pelton, 2017).

Some theorist believe that there are stages in children language development. In the age of 6-8 months babies are in the stage of bubling in which they produce repetitive consonant vocal patterns. At the age of 9 - 18 months, babies are in oneword stage in which they can produce single open-class words or word stems. In addition, in the age of 18-24 months, they achieve the two-word stage which means that they produce mini-sentences with simple semantic relations.Then, the 24-30 month babies show the competence of telegraphic stage which is the competence of producing SVO structure. By the age of 30 months and more, children are in the later multiword stage in which the grammatical and functional structure emerge.

However, the facts show that not every children follows the 'assigned' stages. For some reasons, some children create and develop their own way to communicate with adults. These children produce very variable of speech and frequently unique. In the case of pronounciation, the uniqueness can be traced especially when it is compared to the system of Indonesian vowels and consonants suggested by the experts (Wedhowerti, 2016; Li, et al, 2016).
"False' pronunciation can occur in the intial, medial, and final position. It can be due to the internal as well as external factors (Mulansari, et al, 2014). As observed, there is a pattern in every child's pronunciation. This pattern is assumed to be the clue for the adults to understand their children language since the pronunciation incompetence is very crucial when it comes to communication and being understood (Nosratinia dan Zaker, 2014).

Age, gender, and phonetic ability are among the factors suggested to be influential in the pronounciation competence. The study conducted by Khamkhien (2016) prove the significant influence of the three factors in acquiring pronunciation competence.

The study is aimed at describing the pronunciation pattern of a particular child named Ghazi.

\section{METHODOLOGY}

Ghazi is the subject of the research. He is 2.7 years old, healthy, and energetic. His parents are university graduates. He is surrounded by books for children to read and cartoons from youtube to watch. He communicates and makes friend easily with kids and adults around him.

Data were collected through participant observation. The words pronounced by Ghazi were recorded in the observation sheet as the primary data. After three days observation (22-24 July 2017), the mother were asked to fill in a data table in order to obtain more data to analyze. The data were categorized into unique vocal pronunciation, unique consonant pronunciation, unique consonant addition, unique vocal deletion, 
and unique vocal deletion (Hidayati, 2014).

\section{RESULT AND DISCUSSION}

The results show the pattern of pronunciation as seen in the language produced by Ghazi. The categorization is simpler than those found in the previous study. They are: unique vocal pronunciation, unique consonant pronunciation, and unique consonant deletion.

\section{Unique Vocal Pronunciation}

One of the most challenging vocal phoneme for Ghazi is the / $/$ /. Phoneme /ə/ is frequently pronounced as /כ/ phoneme. The examples are as the following:

1) [dəngar] becomes [dongan]

2) [gəlap] becomes [dəyap]

3) [kəren] becomes [cryen]

4) [pədas] becomes [codas]

5) [sənang] becomes [conay]

From examples (1-5), it is seen that mid central vowel / $\partial /$ becomes open mid back vowel $/ \mathrm{J} /$ in his pronunciation. However, Ghazi had no difficulties to pronounce the open mid front vowel $/ \varepsilon /$. For example,

6) [bebek] is pronounced as [bebek]

7) [lempar] is pronounced as [epan]

8) [jeruk] is pronounced as [jeyuk]

If the $/ \partial /$ in $1-5$ is compared with the $/ \varepsilon /$ in $6-8$, it is found that Ghazi's difficulty is dealing with the mid central vowel /ə/ such as found in [dəngar] and not in the open mid front vowel $/ \varepsilon /$ such as found in [bebsk].

Other data shows that open mid back vowel /ə/ is pronounced as close front vowel /i/ phoneme, such as the example 9 as follows,
9) [səlimut] becomes [tcimut]

Example number 9 needs to pursue since it is a three-syllable word [sə-li-mut] which might be shortened by the subject to be two-syllable word [toi-mut]. However, other three syllabe word he ever produced was [gorilla]' which he consistently pronounced as a threesyllable word [o-i-ya].

\section{Unique Consonant Pronunciation}

The unique pronunciation in the consonants also occur. They occur in the consonant /p/, /b/, /k/, /s/, and /l/.

One of the most challenging consonant phoneme for Ghazi include stop voiceless bilabial /p/. Phoneme /p/ is pronounced as stop voiceless palatal / t6/ or stop voiceless alveolar / $t /$. The examples of the changes are as follows:

10) [pinjam] becomes [t6ijam]

11) [pintar] becomes [tcintan]

12) [pədas] becomes [t6odas]

13) [poli] becomes [t6כyi]

14) [pulpen] becomes [topen]

15) [potong] becomes [toton]

From the examples $10-15$, it is seen that phoneme stop voiceless bilabial /p/ is mostly changed into voiceless palatal / $\mathrm{t} 6$ / or voiceless alveolar / $\mathrm{t}$.

Other challenging phoneme is voiced bilabial /b/. Phoneme /b/ is very often changed into phoneme voiced alveolar /d/. For example,

16) [baru] becomes [dayu]

17) [bola] becomes [dəya]

18) [bangun] becomes [dangun]

19) [bawah] becomes [dawah]

The example 16 - 19 show that phoneme voiced bilabial / b/ is very often pronounced as phoneme voiced alveolar /d/. However there are some exceptions too. For example, 
20) [buka] becomes [kuka]

Voiceless velar phoneme / $\mathrm{k} /$ is also challenging for Ghazi. This phoneme is produced as voiceless alveolar $/ \mathrm{t} /$ as in the examples,

21) [kiri] becomes [tciyi]

22) [keras] becomes [toyas]

Example 21 -22 show that Voiceless velar phoneme $/ \mathrm{k} /$ is pronounced as voiceless alveolar $/ \mathrm{t} /$.

Phoneme fricative voiceless alveolar $/ \mathrm{s} /$ is also a real challenge the child. All the /s/ phonemes become stop voiceless palatal / t 6 / as follows,

23) [sisir] becomes [tccicin]

24) [susun] becomes [t6utcun]

25) [solat] becomes [tcoyat]

The example $23-25$ show that phoneme fricative voiceless alveolar /s/ is pronounced as stop voiceless palatal / $\mathrm{t} 6 /$.

Unique pronunciation of / $/$ occurs particularly when the $/ \mathrm{l} /$ is in the initial position of the second syllable. In this case, the /l/ was pronounced as / $y /$ as follows,

26) [gelap] became [dэyap]

27) [gorilla] became [jiya]

28) [hilang] became [iyang]

29) [malas] became [ayas]

30) [tolong] became [toysn]

Examples 26-30 represent the lateral voiced alveolar $/ \mathrm{l} /$ is prounced as voiced palatal $/ \mathrm{j} /$.

In the final position phoneme the lateral voiced alveolar $/ \mathrm{l} /$ is pronounced as nasal voiced alveolar $/ \mathrm{n} /$. Some examples are as follows:

31) [ambil] became [abin]

32) [mobil] became [эbin]

33) [bantal] became [atan]

The same case occurs with phoneme $/ \mathrm{r} /$ in which it is pronounced as nasal voiced alveolar $/ \mathrm{n} /$ When it is in the final position, the rhotic voiced alveolar $/ \mathrm{r} /$ phoneme is pronounced as $/ \mathrm{n} /$ as follows,

34) [kamar] became [taman]

35) [pintar] became [tcintan]

36) [tidur] became [tidun]

Example number 34-36 show that

the rhotic voiced alveolar $/ \mathrm{r} /$ is pronounced as nasal voiced alveolar $/ \mathrm{n} /$.

3.3 Unique Consonant Deletion

Ghazi's speech also show the case of consonant deletion both in the initial position and in the final position. The deletion occurs for the phoneme stop voiced bilabial /b/ and stop voiceless velar $/ \mathrm{k} /$ The examples are,

37) [baju] became [aju]

38) [kambin] became [abin]

Example number 37-38 show the deletion of stop voiced bilabial /b/ and stop voiceless velar $/ \mathrm{k} /$.

Ghazi also perform phoneme deletion in his pronunciation for the lateral voiced alveolar /l/ in his speech such as the examples as follows,

39) [lupa] became [upa]

40) [lempar] became [عpan]

41) [lompat] became [spat]

Example number 39-41 show the deletion of lateral voiced alveolar /l/ in Ghazi's speech.

The same deletion also occurs in dealing with phoneme voiced bilabial $/ \mathrm{m} /$ and voiced alveolar /n/. It is shown in the example as follows,

42) [malas] became [ayas]

43) [merah] became [cyah]

44) [mobil] became [obin]

45) [mэnyst] became [эnyst]

46) [nonton] became [गton] 
Example number 42-46 show the deletion in the pronunciation of voiced bilabial /m/ and voiced alveolar /n/.

Rhotic voiced alveolar $/ \mathrm{r} /$ is also deleted in Ghazi's pronunciation. The data show the examples such as,

47) [rambut] became [abut]

48) [rumah] became [umah]

49) [ribut] became [ibut]

50) [remot] became [عmot]

51) [robot] became [obot]

Example number 47-51 show the deletion of rhotic voiced alveolar / $\mathrm{r} /$.

Another consonat which is deleted is glide voiced bilabial /w/ for [wortəl] which was pronounced as [jtən].

The data above suggest that Ghazi's unique pronunciation shows a specific pattern which might be similar or different in some ways with other children's pronunciation. Knowledge of the pattern in Ghazi's pronunciation not only help parents understand his speech but also as a good resources for linguists to recognize the development in children's speech.

As theoriest have also found that children speech differs from that of adults in several ways, Ghazi's unique pronunciation is also assumed to be the result of his unique articulatory. What is unique in the articulatory of different children might need further study. Physical as well as mental development might involve in the phenomenon. Ghazi's production system which include vocal cords and vocal tract might also be shorter than other children of his age which needs to study further.

The vocabulary and syntax choices are assumed to be not getting any influence from the pronunciation competence. However, since this kind of children are still fighting for being understood by adults, they might choose to speak shorter. This is significant for further researches too.

Other factor which is found to be influential in pronunciation competence is gender (Khamkien, 2010). Ghazi might be one of those boys whose 'ego' makes him careless or 'lazy' in his effort to be understood beside the fact that he is the only child in the family which makes him believed that all attention are poured around him every minute, so the challenge to improve the pronunciation seems to be uninteresting to do.

The average length of time needed by adults especially parents to finally get the pattern of pronunciation might also be interesting to discuss. What factors involve in the harmonius productive and receptive process between both parties is a real challenging question to answer. The questions could be including the factor of parents' age, educational background, and communication intensity with the children, and so on.

\section{CONCLUSION}

Ghazi's unique pronunciation shows a specific pattern. Firstly, The [p] and [b] phonemes become [t6] and [d] as in the example [poli] becomes [t6oyi], [bola] becomes [doya]; Secondly, some phonemes are not spoken at all such as ' $m$ ' in [mobil] which becomes [obin]; Thirdly, phonemes in the final position are pronounced in different phonemes. For example, [apel] becomes [apan], [panjay] becomes [dadan], and [mundur] becomes [undun]; Fourth,c ertain consonants in the initial position are changed but not when they are in the final position. For example, 
' $t$ ' in the initial position is changed such as [təman] becomes [t6oman] but ' $t$ ' in the final position such as [pəsawat]' becomes [t6ut6awat]. Fifth, in pronouncing vowels there are some changes in the phonemes too. For example,[səram],[gəlap], and [kəras] which become [tøoyam], [dəyap], and [toyas] in which that [ə] phoneme becomes [0]. Other vowels do not result in similar difficulties for him.

Further researchers are really important to do to describe the uniqueness of every child's pattern of pronunciation to get insight on how an individual child tries to find his own way to a more accepted pronunciation.

\section{REFERENCES}

Eskenazi M. And Gary P. (2017)l. Pinpointing pronunciation errors in children s speech: examining the role of the speech recognizer. Language Technologies Institute. http://www.daneprairie.com
Hidayati, R. R. N. (2014). Analisis kesalahan pelafalan fonem Bahasa Jawa pada lanjut usia di Panti Sosial Tresna Werdha Yogyakarta unit 'Abiyoso'. Skripsi Program Studi Pendidikan Bahasa Jawa Jurusan Pendidikan Bahasa Daerah Fakultas Bahasa dan Seni Universitas Negeri Yogyakarta.

Khamkhien, Attapol. (2010). Thai learners' english pronunciation competence: lesson learned from word stress assignment. Journal of Language Teaching and Research, Vol. 1, No. 6, pp. 757-764, November 2010.

Li, Huili, et al. (2016). Sound Pattern of Indonesian Vowels. Buku Kumpulan Makalah Kongres Internasional Masyarakat Linguistik Indonesia (KIMLI). 315-318

Mulansari, Ifon. (2014) The analysis of the first year students' errors in pronouncing english words. Journal of English Language Teaching Society (ELTS) Vol. 2 No. 3.

Nosratinia. Mania (2014). An analysis of iranian efl learners'pronunciation errors. International Journal of Language Learning and Applied Linguistics World (IJLLALW) Volume 5 (3), March 2014; 97---108

Wedhowerti. (2016). The phonological adjustment of Dutch loanwords in Indonesian; a study on nouns in clothing and grooming, the house, and modern world. Buku Kumpulan Makalah Kongres Internasional Masyarakat Linguistik Indonesia (KIMLI).909-912. 